\title{
FDI and Economic Growth - Does the Quality of Banking Development Matter?
}

\author{
Nor Hakimah Haji Mohd. Nor, ${ }^{a}$ Soo-Wah Low, ${ }^{b^{*}}$ Abu Hassan Shaari Md Nor, ${ }^{c}$ and \\ Noor A. Ghazali ${ }^{d}$ \\ ${ }^{a}$ Faculty of Management and Muamalah, Kolej Universiti Islam Antarabangsa Selangor, Malaysia. \\ b,d UKM-Graduate School of Business, Universiti Kebangsaan Malaysia, Malaysia. \\ ${ }^{c}$ Faculty of Economics and Management, Universiti Kebangsaan Malaysia, Malaysia.
}

\begin{abstract}
This study examines the role of banking development quality in the FDI-growth nexus from 1998 to 2009. Banking development quality is measured using two standardized intermediation cost indicators and an index of banking development quality that is constructed based on the following indicators: overhead costs to total assets and net interest margin. The results for developed countries show that, on its own, FDI is negatively related to economic growth. However, when FDI is interacted with a banking development quality index, the quality of banking development is found to play a positive role in influencing the effects of FDI on economic growth. This suggests that the quality of banking development serves as an absorptive capacity that allows developed countries to benefit from the positive growth effects of FDI. On the contrary, for emerging countries, the findings indicate that banking development quality plays no role in influencing the impact of FDI on economic growth. This implies that the quality of banking development in emerging countries has yet to reach a level that allows it to importantly influence the growth effects of FDI.
\end{abstract}

Abstrak: Penelitian ini menguji peran pengembangan kualitas perbankan di FDI - pertumbuhan perhubungan 1998-2009. Pengembangan kualitas perbankan diukur dengan menggunakan dua indikator intermediasi biaya standar dan indeks pembangunan kualitas perbankan yang dibangun berdasarkan indikator berikut: biaya overhead terhadap jumlah aktiva dan net interest margin. Hasil untuk negara maju menunjukkan bahwa dengan sendirinya, FDI berhubungan negatif dengan pertumbuhan ekonomi. Namun, ketika FDI berinteraksi dengan perbankan, indeks kualitas pembangunan perbankan ditemukan untuk memainkan peran positif dalam mempengaruhi efek FDI terhadap pertumbuhan ekonomi. Hal ini menunjukkan bahwa kualitas perkembangan perbankan berfungsi sebagai daya serap yang memungkinkan negara maju untuk mendapatkan keuntungan dari efek pertumbuhan positif FDI. Sebaliknya, bagi negara-negara berkembang, temuan menunjukkan bahwa kualitas perkembangan perbankan tidak memainkan peran dalam mempengaruhi dampak FDI terhadap pertumbuhan ekonomi. Ini berarti bahwa kualitas perkembangan perbankan di negara-negara berkembang belum mencapai tingkat yang memungkinkan untuk kepentingan mempengaruhi efek pertumbuhan FDI.

Keywords: banking development quality; economic growth; foreign direct investment

* Corresponding authors. E-mail: swlow@ukm.my, or soowah.low@gmail.com 


\section{Introduction}

For the last two decades, many countries have been making earnest effort to promote their economies as the place for foreign direct investment (FDI, hereafter). The flow of FDI increased sharply in developed and emerging economies that had designated FDI as a major source of economic development (UNCTAD 2010). ${ }^{1}$ FDI has been a capital formation of choice and is identified as one of the most important factors that contribute to economic expansion through its benefits and externalities. Alfaro et al. (2004, 2009) highlight several benefits of FDI that could promote economic growth, for examples, knowledge spillover of technology transfers, introduction of new processes to domestic market, learning-by-observing, training of labour force and managerial skills, among others.

While there is an extensive body of literature that investigates the relation between FDI and economic growth, the empirical findings are ambiguous and inconclusive. On the one hand, there are studies that find a positive relation between FDI and economic growth (see for example, de Mello 1999; Yao and Wei 2007; Vu and Noy 2009; among others). On the other hand, some studies have shown that FDI is negatively related to economic growth ( $\mathrm{Li}$ and Liu 2005; Elia et al. 2009; Doytch and Uctum 2011; among others). There are also studies that find no significant relationship between FDI and growth (Carkovic and Levine 2002; Beugelsdijk et al. 2008; Herzer 2008).

In search of more consistent results, recent literature has turned to the use of ab- sorptive capacity to explain and to investigate the link between FDI and economic growth. Absorptive capacity is described as a pre-requisite that enables a host country to successfully incorporate the benefits and positive impacts of FDI spillovers (Alfaro et al. 2009; Hermes and Lensink 2003). That said, the literature of FDI-growth nexus has been extended with the introduction of financial development as one form of absorptive capacity. Collectively, the studies along this branch of the literature indicate that finance matters for the growth effects of FDI (see for example, Hermes and Lensink 2003; Alfaro et al. 2004; Ang 2009a, and b; Lee and Chang 2009; Azman-Saini et al. 2010; Choong 2012). Financial development of a country has been recognized as one form of absorptive capacity since it has the potential to spur economic growth by resolving various financial market imperfections which in turn allows the benefits of FDI to be materialized. Levine (2005) provides detailed discussion on the following five major functions of a financial system: producing information and allocating capital; monitoring firms and implementing corporate governance; ameliorating risk; pooling of savings; and easing exchange, all of which contribute to promoting economic growth.

So far, existing studies that investigate the role of financial development in the FDIgrowth nexus only focus on the conventional quantitative-based measures of financial development. Thus, these studies provide only partial understanding of the role of financial development in explaining the relation between FDI and economic growth. The employed quantitative-based measures mostly

\footnotetext{
${ }^{1}$ Statistics of FDI as reported by United Nations Conference on Trade and Development (UNCTAD 2010) show increasing amount of FDI in developed and developing countries from 1970 to 2007. However, from 2008 to 2009 the amount fluctuated due to the occurrence of financial crisis.
} 
proxy for financial sector development size in terms of credit issued and hence do not capture the quality aspect of financial development. Anecdotal evidence from the U.S. meltdown and European debt crisis suggests that more developed financial markets do not necessarily imply financial markets of higher quality. That said, this research advances the idea that the lack of banking development quality could potentially limit a country's ability to benefit from the impacts of FDI. We examine the role of banking development quality as a new form of absorptive capacity in enabling a country to capitalize on the growth effects of FDI using two panel datasets over the period from 1998 to 2009. The analyses are conducted for developed and emerging markets separately to determine whether banking development quality serves as an important absorptive capacity in developed and emerging countries. The findings provide insights into the relative importance of the quality dimension of banking sector in these countries. The remainder of the paper is structured as follows. Section II reviews the literature and Section III discusses the data and methodology. Section IV reports the empirical results and Section $\mathrm{V}$ provides a summary and concluding remarks.

\section{Literature Review}

It is well established that a major contribution of foreign investment to the host country comes from its various external effects or spillovers. However, past studies on the effects of FDI on economic growth have shown mixed findings. De Mello (1999) shows that FDI inflows positively affect output growth for a sample of 15 OECD and 17 non-OECD countries over the period of 1970 to 1990 . Using sectoral data for a group of six OECD countries, Vu and Noy (2009) find that FDI significantly and positively affects economic growth both directly and through its interaction with labour. In their study of 29 provinces and municipalities in China over the period of 1979 to 2003, Yao and Wei (2007) conclude that FDI is a powerful driver of economic growth for newly industrialised economies. Many other studies that examine the implications of FDI on economic growth find that FDI contributes negatively to a country's economy. In their study of developed, developing, and transition economies, Görg and Greenaway (2004) conclude that the effects of FDI on growth are mostly negative. Elia et al. (2009) examine the effects of outward FDI on Italian firms over the period of 1996 to 2006 and find that foreign activities have negative impacts on the demand for low skilled workers in the parent company's industrial region as well as on the demand for high skilled workers when FDI are addressed to high income countries. In a recent study, Doytch and Uctum (2011) find that the impact of total FDI on the overall growth in the service-based economies is negative.

There are also some studies indicating that an ambiguous relationship exists between FDI and economic growth. Beugelsdijk et al. (2008) report that, while there exist significant positive growth effects from both horizontal (market seeking) or vertical (effectively seeking) FDIs in developed countries, there is no evidence of significant growth effects in developing countries. Carkovic and Levine (2002) re-examine the relationship between FDI and economic growth over the study period from 1960 and 1995 and find that the exogenous component of FDI does not exert any positive impact on economy growth. They conclude that there is no reliable cross-country empirical evidence that supports FDI's independent contribution to economic growth. Similarly, Herzer (2008) 
also discovers unclear association between FDI and economic growth for a sample of 28 developing countries.

Drawing on the ambiguous and conflicting results of the FDI-growth relationship, recent literature has indentified absorptive capacity of a host country as the key explanatory variable for the varied conclusions. As noted in Azman-Saini et al. (2010), to enable a host country to absorb the benefits from FDI flows, it has to possess specific abilities that allow FDI spillovers to be positively realized. According to Crespo and Fontoura (2007), absorptive capacities of domestic firms and regions are important preconditions for incorporating the benefits of FDIs. Since different countries have different levels of development and local conditions, the impacts of FDI in each country would therefore be different. It is expected that maximum benefits of FDI spillovers can be reaped through higher level of absorptive capacity. As stated in Alfaro et al. (2009), the success of domestic firms is determined to a certain extent, by local characteristics and the inherent weakness of domestic firms may reduce their abilities to absorb new technologies brought by their foreign counterparts. Consequently, this would hold back technological innovation and limit its impacts on the overall economy.

Along the absorptive capacity branch of the literature, several studies have examined the impact of financial development in the FDI-growth link. For example, Hermes and Lensink (2003); Alfaro et al. (2004); Ang (2009a, and b); among others, find that the development of banks and stock market are important preconditions for FDI spillovers to be positively realized. Hermes and Lensink (2003) employ the average value of gross FDI inflow as a percentage of GDP to proxy for FDI, per capita growth rate to measure growth, and the log of private sector bank loan to GDP ratio to measure financial development. In Alfaro et al. (2004), financial development is measured using liquid liabilities, bank assets, private sector credit, and bank credit as employed by King and Levine (1993), and stock market value traded and market capitalization as introduced by Levine and Zervos (1998).

Using a composite index of financial development, Ang (2009a) shows that a more developed financial system facilitates the FDI spillovers associated with the transfer of new technology in a host country. The four indicators used to construct the composite index of financial development are the following ratios: the number of commercial bank offices per 1000 people; M3-M1 to nominal GDP; commercial bank assets to the sum of central bank assets and commercial bank assets; and bank claims on private sector to nominal GDP. Ang (2009b) examines Thailand, as a case study and find that although FDI has negative impact on output in the long run, its impact on the economy is nevertheless strengthened by the level of financial development. Similarly, Lee and Chang (2009), and Azman-Saini et al. (2010) also find that the impact of FDI spillovers on economic growth required a well-functioning financial market. The result of Azman-Saini et al. (2010) based on 91 countries over the period from 1975 to 2005, shows that FDI's impact on growth is positive only when financial development exceeds a threshold level. Azman-Saini et al. (2010) apply the same indicators as Alfaro et al. (2004) to proxy for banking sector development. Similarly, in a recent study, Choong (2012) also finds that a well-developed domestic financial market is a precondition for FDI to affect economic growth positively. 
In the discussion that follows, we provide two motivations for the present study. First, studies on the implications of financial development on the FDI-growth nexus have not been adequately addressed because these studies focus only on the conventional quantitative-based measures of financial development. Thus, these studies provide only partial understanding of the role of financial development in the FDI-growth nexus. As noted by Beck et al. (2010), while quantitative dimensions indicators have been popularly used in the literature, these measures proxy for the size of financial development and, financial sector of bigger size does not always imply that it is better. As Beck et al. (2010: 81-82) remarked '... these size measures are only for the financial sector's function of allocating savings to their best uses. The size indicators do not capture directly the efficiency with which financial institutions and markets undertake this role.' Additionally, anecdotal evidence from the US meltdown and European debt crisis suggests that well-developed financial markets do not necessarily imply financial markets of higher quality. In a recent study, Ju and Wei (2011) model the role of financial systems to determine the patterns of production and trade and find that conventional measure of financial development such as the size of financial market related to GDP does not adequately capture the quality of financial and institutions.

The second motivation is, while several studies have linked the quality aspect of financial development to economic growth, these studies have been conducted at firmspecific level. For example, Jayaratne and Strahan (1996) find that economic growth increases due to improvements in bank lending quality and not due to the increases in lending volume. Bank lending quality is proxied by bank lending activities using total loan and commercial loan. Using point aggregate point estimate of profit and cost efficiency, Hasan et al. (2009) find that higher banking quality is associated with a higher level of economic growth. The quality of financial institutions is measured as the relative ability of banks to intermediate funds which includes the inputs of a bank's demand labor, fixed assets, and borrowed funds at given factor prices in producing customers loans and other earning assets. In the present study, we extend the literature by incorporating the quality aspect of financial development at the country-level in examining the link between FDI and economic growth. We conjecture that the lack of financial development quality could limit a country's ability to absorb the benefits associated with FDI flows. That is, countries with better absorptive capacity as proxied by financial development quality are more likely to benefit more from growth effects of FDI spillovers. A banking sector of good quality eases market frictions and reduces transaction costs and thus improves resource allocation, which in turn has positive repercussion on the economy. As of now, there is no empirical evidence to test the view that the quality dimension of financial development is important in influencing the effects of FDI on economic growth. On that premise, this study aims to fill the gap.

This study incorporates the quality dimension of financial development in examining the role of banking development in the FDI-growth nexus. Jin et al. (2011) highlight that financial development of good quality serves as the backbone of a country's welldeveloped financial system. The findings of Claessens et al. (2001) suggest that banks in low-income countries have significantly higher levels of overhead expense than those in high-income countries. According to 
Claessens et al. (2001), a bank's overhead cost to total assets reflects its deposit and loan operation and signifies the cost of financial intermediation and thus provides indication on banking efficiency. Lensink and Hermes (2004) employ total overhead costs to total assets to measure the costs of banks, and find that foreign bank entry improves the efficiency of domestic banks and thus resulting in lower costs for domestic banks. DemirgucKunt et al. (2004) employs net interest margin and overhead costs as dependent variable to examine the impacts of bank regulations, market structure, and national institutions. The results show that high net interest margins and large overhead expenditure are associated with small banks, banks that hold a low fraction of liquid assets, banks with relatively small amount of capital, banks without substantial income from fee-based activities.

In the present study, banking development quality is measured by intermediation efficiency using two indicators i.e., overhead costs to total assets and net interest margin to examine the role of banking development quality in enabling FDI to promote economic growth. The indicator overhead cost to total assets is employed to proxy for banking development quality because it captures a bank's core functional activity of fund intermediation. Increases in a bank's overhead costs to total assets indicate decreases in a bank's intermediation efficiency implying that banks are not competent both in sourcing for cost-effective funding and in managing their loan portfolios. In other words, banks are not performing the intermediation function efficiently and thus this provides a signal of low banking quality. As a result, capital flows are not directed to their most productive use and this in turn has negative impacts on the economy. Accordingly, based on the above discussion, this study formulates the following hypothesis to examine whether higher quality of banking development as captured by lower bank overhead cost to total assets enhances the positive growth effects of FDI in both developed and emerging countries.

$H_{1}$ : Higher quality of banking development, as captured by higher intermediation efficiency through lower bank overbead cost to total assets, enhances a country's ability to absorb the positive growth effects of FDI.

The findings of Maudos and Solis (2009) indicate that high levels of interest margin of banks in Mexico are driven by high operating costs which resulted in banks charging higher interest rates on credit and imposing lower interest rate on deposits. Their study concludes that a high interest margin reflects high cost of intermediation which consequently impacts economic growth negatively. Similarly, Demirguc-Kunt et al. (2004) employ net interest margin to measure the cost of intermediation and find that higher levels of net interest margins are associated with smaller banks. Beck and Hesse (2009) find that smaller banks and less developed banking systems have higher levels of net interest margin and spread. Collectively, these studies indicate that a higher net interest margin is closely associated with higher costs of intermediation. A high net interest margin suggests that large differences exist between lending and deposit rates and thus implying the presence of high informational asymmetry. This in turn suggests that banks may not be performing their functions efficiently in reducing market frictions. Thus, flows of capitals are not directed to the highest value use which consequently impedes economic growth. That said, decreases in a bank's net interest margin can be taken to imply improvement in intermediation efficiency which 
indicates better banking quality. Based on the above discussion, this study examines whether higher quality of banking development as captured by a lower net interest margin enhances the positive growth effects of FDI in both developed and emerging countries as hypothesizes below.

$H_{2}$ : Higher quality of banking development, as captured by higher intermediation efficiency through lower net interest margin, enhances a country's ability to absorb the positive growth effects of FDI.

Building on the above discussions and in the greater context, this study also employs an overall proxy of banking development quality. This proxy is an equally weighted index of banking development quality that is constructed based on the above-mentioned two intermediation efficiency indicators. The constructed index provides indication on the overall quality of banking development and what follows is the formulated hypothesis.

$H_{3}$ : Higher quality of banking development, as captured by higher intermediation efficiency through higher value of banking development quality index, enhances a country's ability to absorb the positive growth effects of FDI.

\section{Data and Methods}

This study employs static panel regression that includes pooled OLS, random effects and fixed effects models to examine the role of banking development quality in the FDI-growth nexus using two balanced panel datasets over the period from 1998 to 2009. The first dataset includes 11 developed countries and the second dataset consists of 16 emerging countries. The study samples are shown in Appendix A.

Banking development quality is measured using the following two cost interme- diation indicators: bank overhead costs to total assets and net interest margin. We also employ an equally weighted index of banking development quality that is constructed based on the two efficiency indicators. The description for each indicator is available in Beck et al. (2010) and is defined as follows. The indicator overhead costs to total assets is the accounting value of a bank's overhead costs to its total assets, while the indicator net interest margin represents the accounting value of a bank's net interest revenue to its total earning assets. Both indicators measure the level of efficiency with which banks allocate and intermediate funds, which can proxy for banking development quality. According to Claessens et al. (2001), overhead costs to total assets reflects banks' deposit and loan operations and it represents the cost of financial intermediation and thus provides indication on banking efficiency. Their findings show that banks in low-income countries have significantly higher overhead expenses than banks in high-income countries possibly due to the difficulties faced in the loan evaluation process. In their study, Beck and Hesse (2009) employ interest rate margin and interest rate spread to proxy for financial intermediation efficiency in Uganda and find strong evidence that the observed margin differences between Uganda and other countries are mainly driven by institutional deficiencies. Demirguc-Kunt et al. (2004) employ overhead costs and net interest margin as dependent variables to proxy for cost of intermediation and find that smaller banks are associated with higher levels of net interest margins. Both overhead costs and net interest margin result in similar findings. The indicators of bank overhead costs to total assets and net interest margin are employed to measure banking development quality from the dimension of intermediation effi- 
ciency. Given the growth enhancing role of banks, the intermediation efficiency of bank plays important role in facilitating a country's ability to benefit from the growth effects of FDI. For bank overhead costs to total assets, increases in this indicator reflect increases in the operation costs of banks. Since the core functional activity of banks is fund intermediation, this implies that the incurred operation costs to a large extent are associated with banks' inefficiencies in mobilizing resources. If banks are capable of looking for cheaper funding sources and managing the loan portfolio well, this would be reflected in lower overhead costs to total assets which indicates higher level of intermediation efficiency. This indicator directly captures the efficiency with which bank performs its intermediation function and thus signify the quality of banking development of a country. Based on the indicator net interest margin, the quality of banking development can be implied from the spread between lending and deposit rates which is indicative of the level of informational asymmetry in the marketplace. Since banks influence economic growth by reducing market imperfections, a high level of asymmetric information could possibly suggest that banks have not been performing their functions efficiently in easing market frictions. Thus, the quality of banking development in terms of intermediation efficiency can also be inferred from the net interest margin indicator.

Since bank overhead costs to total assets and net interest margin are indicators of financial intermediation cost, to facilitate interpretation of these indicators in relation to banking quality and its effect on economic performance, we standardized each indicator by subtracting its value from 1 . With the standardization procedure, the value of the standardized overhead costs to total assets
$(\mathrm{OVH})$ and the standardized net interest margin (NIM) would now fall in the unit interval. Thus, it follows that, as overhead costs to total assets decreases (i.e., bank operation is more efficient), the standardized value of overhead costs to total assets increases and this signals an improvement in banking development quality. In other words, decreases in a bank's overhead costs to its total assets is equivalent to the increases in the value of this standardized indicator, suggesting that bank is more efficient and thus signals better banking development quality. Similarly, as net interest margin increases (i.e., bank operation is less efficient) the value of the standardized net interest margin decreases and this signals a decline in banking development quality. Large net interest margin suggests that high differences exists between lending and deposit rates which is indicative of high level of informational asymmetry and hence implies that banks are not functioning efficiently in reducing market frictions.

This study employs two-way (cross-section) fixed effects to examine the role of banking development quality in the FDIgrowth nexus. The empirical models are shown as follows:

$$
\begin{aligned}
\mathrm{y}_{\mathrm{i}, \mathrm{t}}= & \alpha+\beta_{1} \mathrm{FDI}_{\mathrm{i}, \mathrm{t}}+\beta_{2} \mathrm{QBD}_{\mathrm{i}, \mathrm{t}}+\beta^{\prime} \mathrm{X}_{\mathrm{i}, \mathrm{t}}+\mu_{\mathrm{i}} \\
& +\varepsilon_{\mathrm{i}, \mathrm{t}} \cdots \ldots \ldots \ldots \ldots \ldots \ldots \ldots \ldots \ldots \ldots \ldots \ldots \ldots \ldots \ldots \ldots \ldots \ldots \ldots \ldots \ldots \ldots \ldots \ldots \ldots \ldots \ldots \\
\mathrm{y}_{\mathrm{i}, \mathrm{t}}= & \alpha+\beta_{1} \mathrm{FDI}_{\mathrm{i}, \mathrm{t}}+\beta_{2} \mathrm{IQBD}_{\mathrm{i}, \mathrm{t}}+\beta_{3}(\mathrm{FDIx} \\
& \mathrm{IQBD})_{\mathrm{i}, \mathrm{t}}+\beta^{\prime} \mathrm{X}_{\mathrm{i}, \mathrm{t}}+\mu_{\mathrm{i}}+\varepsilon_{\mathrm{i}, \mathrm{t}} \ldots \ldots \ldots \ldots . . \\
& \mathrm{t}=1, \ldots, \mathrm{T} ; \mathrm{i}=1, \ldots, \mathrm{N}
\end{aligned}
$$

where subscript $i$ refers to country and $t$ refers to time period; $y$ is the GDP per capita growth (annual \%); FDI is the foreign direct investment net inflow to GDP; $Q B D$ is the banking development quality indicator 
proxied by two intermediation efficiency indicators and an index of banking development quality $(I Q B D)$ constructed based on two intermediation efficiency indicators (bank overhead costs to total assets and net interest margin); FDI $\times I Q B D$ is the interaction term of foreign direct investment and banking development quality. $X$ is the vector of control variables that are known to affect economic growth. These variables are government consumption $(G C)$, defined as the general government final consumption expenditure to GDP, human capital (HC) measured by the average year of secondary schooling (Barro and Lee 2012); financial openness $(F O)$ proxied by the Chinn-Ito Index or $K A O P E N$; and inflation (INF) measured by the GDP deflator in annual percentage; $\mu_{i}$ is the individual effect of a country; $\varepsilon_{i, t}$ is an error term. The sources of data for FDI, GDP growth, and control variables such as government consumption and inflation, are from World Development Indicators (WDI) Database. The intermediation cost indicators are sourced from the World Bank's Financial Development and Financial Structure Dataset; the human capital data are from Barro and Lee's website; and the financial openness data (KAOPEN) are sourced from the Chinn-Ito's website.

\section{Results and Discussions}

\section{Developed Countries}

Table 1 presents the results for the relationship between banking development quality and economic growth as shown in models 1 to 4 for the first panel dataset of 11 developed countries over the period from 1998 to 2009. The Hausman test results indicate that fixed effects are favored over the random effects models. The Redundant test results in- dicate that both cross-section and period are significant and thus the two-way fixed effects model is chosen. The findings of this study sample are therefore drawn from the results of two-way fixed effects models. Models 1 and 2 report the results of Equation [1] where the two efficiency intermediation indicators i.e., overhead costs to total asset and net interest margins are introduced separately into the regression models.

As shown in model 1, the coefficient of overhead costs to total assets is positively and significantly related to economic growth at one percent level. This indicator is closely related to the level of efficiency with which banks perform the functions of intermediating and allocating funds. High overhead expenditure as a share of total asset reflects a bank's cost inefficiency in its operation and signals a decline in banking development quality. Following the standardization procedure, high overhead costs to total assets is now interpreted as being equivalent to low standardized value of this indicator. That said, lower value of the overhead costs to total assets coefficient signals lower banking development quality which in turn may slow down economic progression since banks influence economic growth by reducing market frictions and transaction costs. However, in model 2, the coefficient of net interest margin is not significant.

Model 3 presents results of Equation [1] where the two intermediation efficiency indicators are constructed into a single banking development quality index (IQBD). As reported, the positive and highly significant coefficient of IQBD presents strong evidence indicating that the quality of banking development exerts positive impacts on economic growth. The findings suggest that better banking development quality as characterized by lower level of overhead costs to total assets 
Nor Hakimahetal.

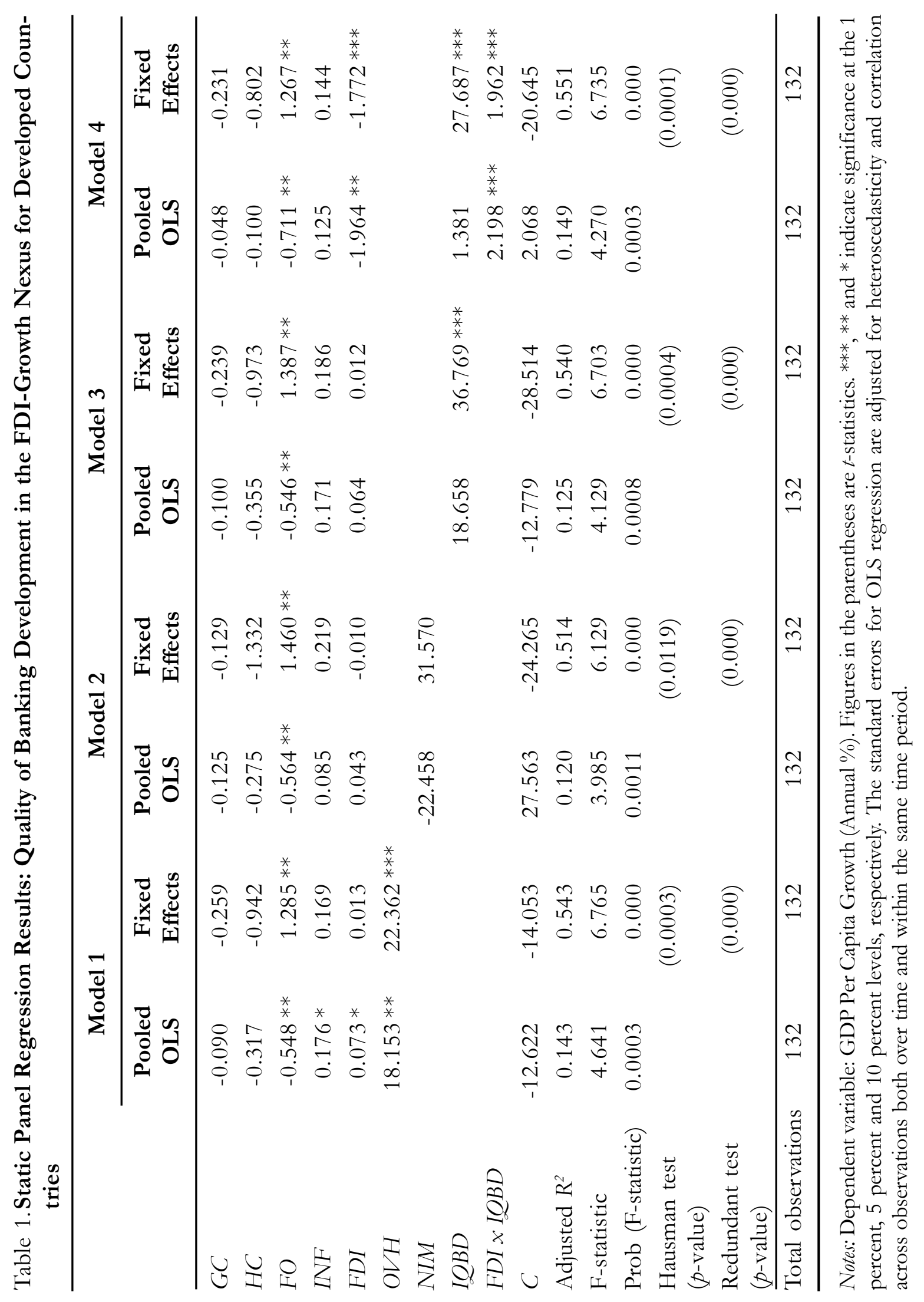


and smaller net interest margin contributes positively to a country's state of economic progression. However, the coefficients of FDI are not significant in models 1 through 3.

Model 4 reports the results of Equation [2] where the role of banking development quality in the FDI-growth nexus is examined using an interaction term (FDI $\times I Q B D)$, i.e., foreign direct investment (FDI) is interacted with the index of banking development quality $(I Q B D)$. In addition to the interaction term, Equation [2] also includes both of the individual indicators, FDI and IQBD to ensure that the interaction term does not proxy for either the standalone FDI or IQBD. The coefficient of the IQBD is found to be positive and highly significant, suggesting that higher level of banking development quality corresponds to higher level of economic growth. On its own, FDI inflows is found to contribute negatively to economic growth. Interestingly, once we include the interaction term $(F D I \times I Q B D)$, we find a significant positive relation between FDI and economic growth. More importantly, the results indicate that the coefficient of the interaction term $(F D I \times I Q B D)$ is positive and highly significant. The highly positive interaction coefficient suggests that banking development quality is an important precondition for FDI to have positive effects on economic growth. Developed countries with better banking development quality are able to absorb better the benefits from FDI spillovers and thus allowing them to enjoy higher economic growth linked to the FDI flows. In other words, the effect of FDI on economic growth in the de- veloped countries is contingent on the level of banking development quality, i.e., a newly identified absorptive capacity of a recipient country. Taken together, the overall results in Table 1 suggest that the quality of banking development serves as an important absorptive capacity that allows the positive growth effects of FDI to be realized. That is, the impact of FDI on economic growth is found to be dependent on this newly identified absorptive capacity that emphasizes on the quality dimension of banking sector development.

\section{Emerging Countries}

Table 2 reports the results for the relationship between banking development quality and economic growth for the second panel dataset consisting of 16 emerging countries over the period from 1998 to 2009 as shown in models 1 to 4 . The Hausman test results indicate that fixed effects are favored over the random effects models. The Redundant test results indicate that both cross-section and period are significant and thus the twoway fixed effects model is chosen. The findings of this study sample are therefore drawn from the results of two-way fixed effects models. For emerging countries, as shown in model 1 , the coefficient of overhead costs to total assets is positively and significantly related to economic growth at one percent level. In model 1, the result consistently shows that higher standardized bank overhead costs to total assets (i.e. lower bank overhead costs to total assets) strongly associates with a higher level of economic growth. However, 
Nor Hakimahetal.

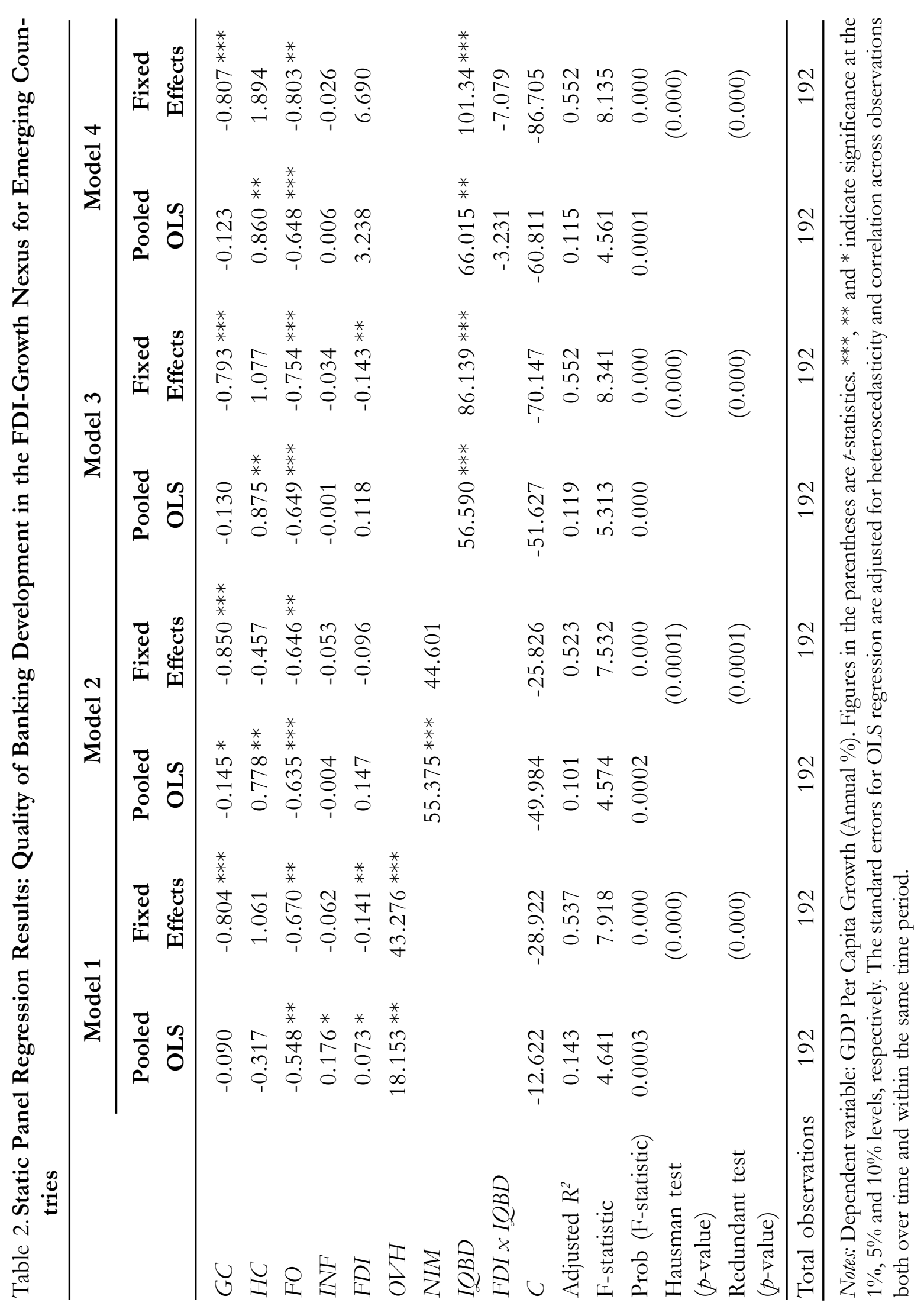


in model 2, the coefficient of net interest margin is not significant.

Model 3 presents results of Equation [1] where the two standardized intermediation efficiency indicators are constructed into a single banking development quality index $(I Q B D)$. The coefficient of IQBD is consistently found to be positive and highly significant indicating that the quality of banking development exerts positive impacts on economic growth. This finding suggests that higher quality of banking development that is captured by lower level of overhead costs to total assets and smaller net interest margin contributes positively to the economic growth in the emerging countries. The coefficients of FDI are negative and significant at five percent level in models 1 and 3 .

Model 4 reports the results of Equation [2] where the role of banking development quality in the FDI-growth nexus is examined using an interaction term $(F D I \times I Q B D)$, i.e., foreign direct investment (FDI) is interacted with the index of banking development quality $(I Q B D)$. Similarly, both of the individual indicators, FDI and IQBD are included in the model to ensure that the interaction term does not proxy for either the standalone FDI or $I Q B D$. The coefficient of the IQBD is found to be positive and highly significant, suggesting that higher level of banking development quality corresponds to higher level of economic growth. However, for emerging countries, the results indicate that the coefficient of the interaction term $(F D I \times I Q B D)$ is not significant. These results suggest that, for emerging countries, quality of banking development does not serve as absorptive capacity in enabling the countries to realize the positive growth effects of FDI. In other words, the effect of FDI on emerging countries' economic growth is not contingent on the level of banking development quality.

\section{Results Summary}

Taken together, the results for developed countries suggest that the quality dimension of banking development matters in order for FDI to serve as an important driver of economic growth. The overall quality of banking development as proxied by the index of banking development quality is shown to be positively related to economic growth in developed countries. However, for the impact of FDI, while on its own it is negatively related to economic growth, but when the impact of FDI is assessed together with the quality of banking development, it is shown to contribute positively to economic growth. These findings imply that the quality of banking sector development in developed countries contributes to enhancing a country's ability to take advantage of FDI spillovers. In other words, banking development quality is considered as one form of absorptive capacity that allows developed countries to absorb the positive growth effects of FDI. On the contrary, the results for emerging countries show that the quality of banking development plays no role in influencing the impact of FDI on economic growth. That is, in emerging countries, the quality dimension of banking development has yet to represent an absorptive capacity in facilitating the growth effects of FDI. Nevertheless, for emerging countries, the quality of banking development, on its own, is shown to promote economic growth and such findings are broadly consistent with the financial development literature that points toward the growth enhancing role of banks (King and Levine, 1993; Beck et al., 2000; DemirgucKunt and Maksimovic, 2002; among others). 
The findings that the quality dimension of banking development constitutes an important element in influencing the impact of FDI on economic growth for developed countries but not for emerging countries somewhat point out the disparities in banking sector development between developed and emerging countries. The results imply that the quality of banking development in emerging countries has yet to reach a level that allows it to importantly influence the growth effects of FDI.

\section{Conclusion}

This study presents new evidence for the role of banking development quality in the FDI-growth nexus using two panel datasets categorized into developed and emerging countries over the period from 1998 to 2009. In particular, we examine if countries with higher banking quality can capitalize more on the growth effects of FDI. Existing studies on the implications of financial development in the FDI-growth nexus employ measures focusing only on quantitative-based indicators of financial development. The present study highlights the importance of the quality aspect of banking development in the FDI and economic growth link. The key results are as follows. Although higher banking quality in emerging countries is associated with higher GDP growth, it does not serve as absorptive capacity in realizing the positive growth effects of FDI. However, for developed countries, while FDI by itself is found to be inversely related to economic growth, interesting results emerge when FDI is interacted with the index of banking development quality. The highly positive interaction coefficient indicates strong evidence that banking development quality in developed countries serves as an important precondition for FDI to have positive effects on economic growth. That means it can be expected that countries with the same levels of FDI inflows could have different levels of economic growth, depending on the levels of their banking development quality. Such findings suggest that the quality of banking development in developed countries serves as a newly identified absorptive capacity that is critical in assessing the impacts of FDI on economic growth. Taken together, our findings imply that a country's policy framework for financial sector development should also emphasize the quality aspect of banking sector development.

\section{References}

Alfaro, L., A. Chanda, S. Kalemli-Ozcan, and S. Sayek. 2004. FDI and economic growth: the role of local financial markets. Journal of International Economics 64: 89 -112.

Alfaro, L., S. Kalemli-Ozcan, and S. Sayek. 2009. FDI, productivity and financial development. The World Economy 32 (1): 111-135.

Ang, J. B. 2009a. Financial development and the FDI-growth nexus: the Malaysian experience. Applied Economics 41: 1595-1601.

Ang, J. B. 2009b. Foreign direct investment and its impact on the Thai economy: the role of financial development. Journal of Economics and Finance 33: 316-323.

Azman-Saini, W. N. W., S. H. Law, and A. Abdul Halim. 2010. FDI and economic growth: new evidence of the role of financial markets. Economics Letters 210: 211-213. 
Barro, R.J., and J.-W Lee. 2012. A new data set of educational attainment in the world, 1950-2010. Journal of Development Economics. Available from: http://dx.doi.org/10.1016/j.jdeveco.2012.10.001

Beck, T., A. Demirguc-Kunt, and R. Levine. 2010. Financial institutions and markets across countries and over time: the updated financial development and structure database. The World Bank Economic Review 24 (1): 77-92.

Beck, T., and H. Hesse. 2009. Why are interest spreads so high in Uganda? Journal of Development Economics 88: 192-204.

Beck, T., R. Levine, and N. Loayza. 2000. Finance and the Sources of Growth. Journal of Financial Economics 58: 261-300

Beugelsdijk, S., R. Smeets, and R. Zwinkels. 2008. The impact of horizontal and vertical FDI on host's country economic growth. International Business Review 17: 452-472.

Carkovic, M., and R. Levine. 2002. Does foreign direct investment accelerate economic growth? Working Paper. University of Minnesota Department of Finance.

Choong, C. K. 2012. Does the domestic financial development enhance the linkages between foreign direct investment and economic growth? Empirical Economics 42: 819-834.

Claessens, S., A. Demirguc-Kunt, and H. Huizinga. 2001. How does foreign entry affect domestic banking markets? Journal of Banking and Finance 25: 891-911.

Crespo, N., and M. P. Fontoura. 2007. Determinant factors of FDI spillovers - what do we really know? World Development 35(3): 410-425.

De Mello, Jr., L. R. 1999. Foreign direct investment-led growth: evidence from time series and panel data. Oxford Economic Papers 51: 133-151.

Demirguc-Kunt, A., L. Laeven, and R. Levine. 2004. Regulations, market structure, institutions, and the cost of financial intermediation. Journal of Money, Credit and Banking 36(3): 593-622.

Demirguc-Kunt, A., and V. Maksimovic. 2002. Funding Growth in Bank-based and Market-based Financial System: Evidence from Firm Level Data. Journal of Financial Economics 65: 337-363.

Doytch, N., and M. Uctum. 2011. Does the worldwide shift of FDI from manufacturing to services accelerate economic growth? A GMM estimation study. Journal of International Money and Finance 30: 410-427.

Elia, S., I. Mariotti, and L. Piscitello. 2009. The impact of outward FDI on the home country's labor demand and skill composition. International Business Review 18: 357-372.

Görg, H., and D. Greenaway. 2004. Much ado about nothing? Do domestic firms really benefit from foreign direct investment? The World Bank Research Observer 19(2): 171-197.

Hasan, I., M. Koetter, and M. Wedow. 2009. Regional growth and finance in Europe: is there a quality effect of bank efficiency? Journal of Banking \& Finance 33: 1446-1453.

Hermes, N., and R. Lensink. 2003. Foreign direct investment, financial development and economic growth. The Journal of Development Studies 40(1): 142-163.

Herzer, D., S. Klasen, and D. F. Nowak-Lehmann. 2008. In search of FDI-led growth in developing countries: the way forward. Economic Modelling 25: 793-810.

Jayaratne, J., and P. E. Strahan. 1996. The finance-growth nexus evidence from bank deregulation. The Quarterly Journal of Economics 111(3): 639-670. 
Jin, J. Y., Kanagaretnam, K. and Lobo, G. J. 2011. Ability of accounting and audit quality variables to predict bank failure during the financial crisis. Journal of Banking and Finance 35:2811-2819.

Ju, J., and S. J. Wei. 2011. When is quality of financial system a source of comparative advantage? Journal of International Economics 84: 178-187.

King, R. G., and R. Levine. 1993. Finance and growth: Schumpeter might be right. The Quarterly Journal of Economics 108(3): 717-737.

Lee, C. C., and C. P. Chang. 2009. FDI, financial development and economic growth: international evidence. Journal of Applied Economics 12(2): 249-271.

Lensink, R. and Hermes, N. 2004. The short-term effects of foreign bank entry on domestic bank behavior: does economic development matter? Journal of Banking \& Finance 28: 55-568.

Levine, R. 2005. Finance and growth: Theory and evidence. In Aghion, P., and S. Durlaff (Eds.), Handbook of Economic Growth. The Netherlands: Elsevier Science.

Levine, R., and S. Zervos. 1998. Stock markets, banks and economic growth. American Economic Review 88 (3): 537-558.

Li, X., and X. Liu. 2005. Foreign direct investment and economic growth: an increasingly endogenous relationship. World Development 33 (3): 393-407.

Moudos, J., and L. Solis. 2009. The determinants of net interest income in the Mexican banking system: an integrated model. Journal of Banking and Finance 33: 1920-1931.

The Chinn-Ito Index. Available from: http://web.pdx.edu/ ito/Chinn-Ito_website.htm.

UNCTAD. 2010. World Investment Report 2010. Investing in a Low-Carbon Economy. New York and Geneva: United Nations.

Vu, T. B., and I. Noy. 2009. Sectoral analysis of foreign direct investment and growth in the developed countries. International Financial Markets, Institutions and Money 19: 402-413.

World Bank, World Databank, World Development Indicators. Available from: http://databank.worldbank.org/ $\mathrm{ddp} /$ home.do

Yao, S., and K. Wei. 2007. Economic growth in the presence of FDI: the perspective of newly industrializing economies. Journal of Comparative Economics 35: 211-234. 
Gadjah Mada International Journal of Business -September-December, Vol. 15,No.3, 2013

\section{Appendix A}

List of countries in the samples of study

\begin{tabular}{llclll}
\hline No. & Developed Countries & No. & Emerging Countries & \\
\hline 1 & Australia & 1 & Argentina & 12 & Peru \\
2 & Canada & 2 & Chile & 13 & Philippines \\
3 & Hungary & 3 & China & 14 & Russian Federation \\
4 & Israel & 4 & Colombia & 15 & South Africa \\
5 & Italy & 5 & Egypt & 16 & Thailand \\
6 & Japan & 6 & India & & \\
7 & Korea, Rep. & 7 & Indonesia & & \\
8 & Poland & 8 & Jordan & & \\
9 & Singapore & 9 & Malaysia & & \\
10 & Spain & 10 & Mexico & & \\
11 & United States & 11 & Morocco & & \\
\hline
\end{tabular}


